\title{
LAS HUELLAS DE LA CRIMINOLOGÍA CRÍTICA EN LA OBRA DEL PROFESOR JUAN BUSTOS
}

\author{
Ana María Morales Peillard*
}

\begin{abstract}
I. Introducción; II. El desarrollo de la criminología crítica y su influencia en el pensamiento criminológico de Bustos: La criminología crítica: i.- La criminología crítica en Norteamérica; ii.- La criminología crítica en Gran Bretaña; iii.- La criminología crítica en otros países; iv.- Críticas y autocríticas; v.- Bustos y la criminología crítica; III. La reformulación de la dogmática a partir de los postulados de la criminología crítica: La revisión de los principios del derecho penal moderno; Revisión de la teoría de la norma jurídica; Revisión de la teoría del bien jurídico; Revisión de la teoría de la pena; Reformulación de la teoría penal desde una perspectiva político criminal: posición de Bustos; IV. A modo de epílogo.
\end{abstract}

\section{Introducción}

Una de las áreas que exploró el Profesor Bustos, particularmente durante su experiencia en el exilio, fue la de la criminología. En Barcelona, junto a Roberto Bergalli y Teresa Millares, con ocasión de las cátedras que dictaran en el Instituto de Criminología de la Universidad de Barcelona, surgió la idea de hacer un repaso sobre la evolución del pensamiento criminológico, pero particularmente la de dar a conocer aquellas teorías alternativas que, atendida la falta de heterogeneidad del discurso criminológico de España, no habían sido difundidas de manera general. ${ }^{1}$ Fue así que, con la publicación de "El Pensamiento criminológico", en 1983, junto con realizar un recorrido crítico a las teorías tradicionales, se expuso por primera vez, de manera detallada, los postulados de la criminología crítica al mundo hispanoparlante, que ya venía desarrollándose hace más de una década por los teóricos norteamericanos Chambliss, Quinney y Platt; y los ingleses Young, Taylor y Walton, entre otros.

Como veremos, la criminología crítica tuvo una influencia poderosa en la obra de Bustos. En efecto, ésta permeó sus escritos de manera determinante, toda vez que, a partir de los postulados de esta corriente, él se permitió repensar los elementos de la dogmática para efectos de precisar sus construcciones concretas al interior del derecho penal. Éste es quizás uno los puntos más brillantes de la obra de Bustos, en la medida que en sus escritos emprende una de las tareas varias veces planteada -pero jamás concretada- por los criminólogos críticos de desarrollar a partir de las proposiciones de dicha corriente, una teoría normativa en que se

\footnotetext{
*Abogado U. de Chile, Master en Política Criminal, London School of Economics and Polítical Science. Académica del programa de Magíster en Criminología y Justicia Penal de la Universidad Central. Jefa de la División de Defensa Social del Ministerio de Justicia. Colaboradora del Centro de Estudios de la Justicia de la Facultad de Derecho de la Universidad de Chile.

1 BERGALLI/ BUSTOS/ MILLARES, El pensamiento criminológico, Tomo I, Editorial Temis, Bogotá, 1983, pp. 5- 12.
} 
Morales - Las huellas de la criminología crítica...

vieran reflejados sus postulados. Así, para Bustos, el asunto es claro: "Criminología crítica implica derecho penal crítico y política criminal crítica, esto es, llevar el sistema hasta sus límites para someterlo a constante revisión".2

Considerando dicha influencia, el presente trabajo pretende efectuar un repaso de los principales planteamientos de la criminología crítica, para luego dar a conocer cómo dichos postulados fueron recogidos en las construcciones dogmáticas, plasmadas en lo que Bustos denominó "las bases críticas de un nuevo derecho penal". ${ }^{3} \mathrm{Al}$ respecto y particularmente antes de comenzar cualquier análisis de dicha línea de trabajo, es necesario tener presente que tomar como referente a la criminología crítica trae aparejado necesariamente que se repliquen a su vez muchas de las objeciones que se han efectuado a dicha corriente de pensamiento, las cuales serán analizadas en el presente trabajo, de manera de exponer las complejidades que importa recoger sus postulados. Como veremos, el citado autor se hizo cargo de una de las críticas importantes, asumiendo, como se señaló anteriormente, la tarea de plasmar sus postulados en una teoría normativa distinta de la tradicional, cuestión que lo haría destacarse como uno de los más brillantes penalistas chilenos.

\section{El desarrollo de la criminología crítica y su influencia en el pensamiento criminológico de Bustos}

En el tomo II de sus Obras completas, Bustos comienza planteando que la "criminología crítica, ha sustituido el examen pluri y multidisciplinario, como mera sumatoria de análisis, por la globalidad del estudio de la cuestión criminal". ${ }^{4}$ Para él, la criminología crítica importa "someter a revisión el control", donde el derecho penal, como expresión concreta del poder político, no es sino un "sub sistema de control". ${ }^{5}$ De ahí que uno de sus más importantes planteamientos radicara en la necesidad de revisar críticamente el derecho penal y la política criminal.

Como se puede observar fácilmente de la lectura de su obra, Bustos hace en ella constante alusión a la criminología crítica como fuente de justificación de la necesidad de revisar los contenidos del derecho penal. Sin embargo, él personalmente no analizó en extenso sus postulados. En efecto, en El Pensamiento criminológico, que editó con Teresa Millares y Roberto Bergalli, -que contenía una exposición y reflexión crítica de la historia de la criminología y en la que colaboraron otros autores-, el capítulo destinado a analizar los fundamentos de esta corriente crítica, fue desarrollado precisamente por este último autor.

\footnotetext{
2 BUSTOS, Obras completas, control social y otros cambios, Tomo II, Ediciones Jurídicas, Santiago, 2007, pp. 10.

${ }^{3}$ BUSTOS, Derecho Penal, Parte General, Tomo I, Ediciones Jurídicas, Santiago, 2007, pp. 21.

4 Op. cit., Tomo II, pp. 10.

${ }^{5}$ Ibid
} 
Atendido lo anterior, dedicaremos los próximos párrafos a exponer los principales postulados y exponentes de la corriente criminológica que Bustos hizo suya en su obra, mostrando las distintas visiones y planteamientos que surgen a partir de ella, de manera de entender la influencia en su obra. Ésta, sin duda, no es una tarea fácil, pues como han señalado algunos autores, en sus postulados se "parecían más en lo que criticaban, que en lo que proponían", 6 y ha sido objeto, como veremos, de duras críticas, autocríticas y reformulaciones, que hacen de su examen algo complejo.

\section{La criminología crítica}

El término "criminología crítica", está inspirado en la tarea desarrollada por la Escuela de Frankfurt y comenzó a gestarse a partir de los agitados años setenta, con las primeras críticas al sistema de control establecido por un orden social cuestionado. En esa línea, las concepciones criminológicas positivistas empezaron a ser rechazadas por esta nueva corriente que percibía dichas posturas más bien como instrumento de legitimación del orden legal y social constituido. ${ }^{7}$ A lo anterior, se suman algunas críticas de fines de los años sesenta a la Teoría del Etiquetamiento o labelling approach, las que si bien destacan sus aportes, en la medida que produjo el denominado "cambio de paradigma" -concentrando el estudio del delito en la reacción social y no en la acción- critican el hecho de presentar al infractor como un sujeto excesivamente pasivo y, por otro lado, el hecho de no abordar la problemática de los delitos de cuello blanco. ${ }^{8}$ Así, con el objeto de esbozar concepciones de un orden social más pluralista, en especial en materia penal, sucedió que diversos autores comenzaron a revisitar aquellas doctrinas de corte marxista, surgiendo la llamada "criminología crítica", "criminología radical" o "la nueva criminología".

Este nuevo enfoque se condecía además con el clima político de los años setenta. Así, como señala Larrauri, las revueltas estudiantiles, las manifestaciones pacifistas, los movimientos a favor de los derechos civiles, los nuevos estilos de vida, el surgimiento de la nueva izquierda y la subsecuente criminalización de estas actividades otorgarían credibilidad a la idea de que "el control penal produce desviación"?

\footnotetext{
${ }^{6}$ En ese sentido ANITUA, parafraseando a COHEN en Imágenes de la Desviación. ANITUA, Historias de los pensamientos criminológicos, Editores del Puerto, Buenos Aires, 2005, pp. 407.

7 BERGALLI, El pensamiento crítico y la criminología, en BERGALLI/BUSTOS/MILLARES, Op. cit; pp. 181 y ss, ANITUA, Op. cit., pp. 407 y ss.

${ }^{8}$ LARRAURI, La Herencia de la criminología crítica, $2^{\circ}$ Ed., Siglo veintiuno de España Editores, Madrid, 1991, pp. 102.

${ }^{9}$ Op. cit., pp. 2.
} 
Morales - Las huellas de la criminología crítica...

\section{i.- La criminología crítica en Norteamérica}

Haciendo un breve repaso de sus principales precursores, encontramos en Estados Unidos los postulados de William Chambliss, quien en su obra El Soborno. De pequeños pillos hasta el Presidente, de 1978, plantea que la criminalidad es un resultado de las imposiciones culturales relacionadas con el consumo y de las necesidades materiales fomentadas por el proceso de explotación de plusvalía. ${ }^{10}$ En efecto, y como plantean Downes y Rock en su obra, Chambliss da a conocer su mayor hallazgo: que la mano oculta del crimen organizado en dicho país no es "la mafia", sino que los principales representantes de la clase dominante de la ciudad. ${ }^{11}$ En consecuencia, para este autor, el crimen no es un producto de una eficiente política económica, sino más bien "el" principal producto de la política económica; así, la lógica del capitalismo es una lógica donde el surgimiento de la red del crimen es inevitable. ${ }^{12}$ Esta visión, lógicamente, nos acerca a los postulados funcionalistas de la anomia de Merton, y en efecto, sus rastros se verán presentes en muchos de los autores de corte crítico, como lo observaremos en los siguientes postulados.

Richard Quinney, por otro lado, si bien presenta un proceso evolutivo en su obra, plantea, tomando como base la teoría marxista del nacimiento y fines del Estado burgués, que éste tendría la función de legitimar el modo de producción capitalista atribuyendo sanciones legales generales a los intereses de una minoría y protegiendo tales intereses con el uso de la fuerza. ${ }^{13}$ Como señala Bergalli, Quinney desarrolla una filosofía crítica del orden legal, entendiendo que los pensamientos filosóficos del positivismo, el construccionismo social y buena parte del pensamiento fenomenólogico han concebido y legitimado el sistema legal como la fuerza necesaria para mantener el orden de la sociedad capitalista, y donde el derecho penal constituye la base de aquel orden. Así, para este criminólogo, el derecho penal es el instrumento coercitivo del Estado, empleado por el Estado y su clase dominante para mantener el orden socio-económico existente. ${ }^{14}$

Otro autor norteamericano, de gran influencia en el pensamiento crítico, fue Anthony M. Platt, quien a partir de un examen de la ideología paternalista tutelar de los tribunales especiales de menores de los Estados Unidos de fines del siglo XIX, planteó en su obra Los salvadores de los niños, de 1969, que la ideología subyacente a los fines altruistas de la intervención es una de carácter eminentemente político, de prevenir la rebelión juvenil contra el sistema social y de educar a los jóvenes de las clases inferiores para el trabajo e inculcarle en definitiva los valores de la clase burguesa. Posteriormente, a través de un estudio de las estadísticas policiales, Platt extrajo que el delito es producido por individuos

\footnotetext{
${ }^{10}$ Citado por ANITUA, Op. cit., pp. 408.

11 DOWNES/ROCK, Understanding Deviance, $4^{\circ}$ Ed., Oxford University Press, Oxford, 2003, pp. 272.

12 Ibid.

${ }^{13}$ QUINNEY, Critique of Legal Order, citado por BERGALLI, Op.cit., pp. 211.

14 Op. cit., pp. 212.
} 
provenientes de los estratos bajos, particularmente negros y desempleados. Para él, el delito no depende exclusivamente de la pobreza, sino que más bien es producto de condiciones "ideológicas, de las relaciones sociales desmoralizantes y de la ética individualista que caracterizan al modo capitalista de producción en su más alto nivel del desarrollo". ${ }^{15}$

\section{ii.- La criminología crítica en Gran Bretaña}

Los mayores exponentes de la criminología crítica británica son, sin duda, Ian Taylor, Paul Walton y Jock Young. Ellos constituyen, como señalan Downes y Rock, el "más vigoroso intento de suplantar los enfoques vigentes con una alternativa neo-marxista", ${ }^{16}$ procurando entregar con su libro La Nueva Criminología, de 1973, una completa teoría social de la conducta desviada.

La citada obra comienza con un recorrido reflexivo crítico del pensamiento criminológico, que se inicia con la escuela clásica y positivista, y continúa con el análisis de las distintas visiones sociológicas: la estructural funcionalista y sistémicas principalmente a través de los escritos de Durkheim y Merton; ecológicas y ambientalistas representadas en las visiones de la Escuela de Chicago; de la reacción social y el enfoque interaccionista de la teoría del etiquetamiento; teorías del proceso social y del control; las teorías criminológicas de los ya desaparecidos países socialistas, principalmente a través de un análisis de los escritos de Marx, Engels y Bonger, y finalizando, antes de formular su propio planteamiento, con una descripción de las obras de otros teóricos críticos, a saber, Dahrendorf, Turk, y la del ya mencionado Quinney, entre otros autores.

Hasta ahí la nueva criminología es, como plantea Cohen, "esencialmente una historia de las ideas pasadas, presentadas en forma más o menos cronológica". ${ }^{17}$

Luego, junto con reprochar el forzado divorcio entre la criminología y la sociología que propugnó -a juicio de estos criminólogos críticos británicosMerton, se encargan de ensalzar la visión de la teoría del etiquetamiento y los aportes de los teóricos del control, como David Matza, en la medida que lograron, como ellos señalan, que la criminología "volviera a ocuparse de las grandes cuestiones de la estructura social y los ordenamientos sociales fundamentales que sirven de marco al proceso del delito". ${ }^{18}$ En ese sentido, agregan que nuevamente "tenemos ante nosotros la cuestión básica de la relación entre el hombre y las estructuras de poder, dominación y autoridad, y la capacidad de los hombres para hacer frente a esas estructuras con actos de delito, desviación y disenso; una vez

\footnotetext{
15 Citado por BERGALLI, Op. cit., pp. 218.

${ }^{16}$ DOWNES/ROCK, Op. cit., pp. 263. La traducción es de la autora.

${ }^{17}$ COHEN, Prólogo a LARRAURI, Op. cit., pp. xii.

18 TAYLOR/WALTON/YOUNG, La nueva criminología, $3^{\circ}$ Ed, Amorrortu Editores, Buenos Aires, 2007 , pp. 304.
} 
Morales - Las huellas de la criminología crítica...

más, entramos en el ámbito de la teoría social misma". ${ }^{19}$ En esa línea, a partir de sus postulados críticos, plantean que una correcta teoría social debe necesariamente estar libre de supuestos biológicos y psicológicos, y asumen la tarea de perfilar aquellos requisitos formales y sustantivos de una teoría plenamente social de la desviación, que pueda explicar las formas que asume el control social y la conducta desviada en sociedades "desarrolladas", entendiendo por estas últimas aquellas que se caracterizan por el "predominio de una forma capitalista de producción, por una división del trabajo que implica el crecimiento de ejércitos de 'expertos' (...) y, en la actualidad, por la necesidad de segregar, en hospitales mentales, cárceles e instituciones para menores, a una cantidad cada vez mayor de sus miembros, considerando que deben ser controlados". ${ }^{20}$

En ese orden de ideas, los citados autores desarrollan, al final de su obra, de manera críptica y breve, los que debieran ser los elementos formales de la teoría social de la desviación, entendiendo por éstos: los orígenes mediatos e inmediatos del acto desviado, ${ }^{21}$ el acto en sí mismo ${ }^{22}$ y los orígenes mediatos e inmediatos de la reacción social..$^{23}$ En efecto, estos son los elementos que, necesariamente, deben estar presentes en una teoría social de la desviación y, como destaca Bergalli, al atribuirle al sujeto desviado una conciencia de sus propias acciones, también le muestra las posibilidades de dar una solución a sus problemas fundamentales. ${ }^{24}$ Así, estos autores se hacen cargo de una de las críticas que formularan

\footnotetext{
${ }^{19}$ Ibid.

20 Op. cit., pp. 305.

21 Conforme, Taylor, Walton y Young, el elemento mediato del acto desviado supone que el acto debe situarse en sus orígenes estructurales más amplios, reconociendo por ende, al hombre no como un individuo atomizado, sino que entendiéndolo dentro de situaciones estructurales, como la pertenencia a una subcultura, o más bien a una denominada economía política del delito; mientras que de acuerdo a los elemento inmediato del acto desviado, la teoría debe explicar, de qué manera, las exigencias estructurales permean los distintos niveles de la estructura social, generando diferentes interpretaciones, reacciones y usos por parte de los integrantes de dichos niveles, debiendo acercarnos a una psicología social del delito. Ibid., pp. 306-307.

${ }^{22} \mathrm{El}$ elemento formal del acto en sí mismo, supone que la teoría social debe ser capaz de explicar aquellas diferencias que se producen entre nuestras creencias y las acciones que desarrollamos, otorgando una suerte de ajuste, para aquellos casos en que la racionalidad de la elección no logra plasmarse en los actos deseados y comprender las limitaciones con que dicha racionalidad se encuentra, debiendo proporcionar una explicación de la real dinámica social a la que son sometidos nuestros actos. Ibid., pp. 307-308.

${ }^{23}$ El elemento inmediato de la reacción social, supone que la teoría social debe ser capaz de explicar la reacción inmediata, tanto de los agentes de control formal como informal, considerando la gama de opciones de que dispone y que resulten a su vez determinantes en la generación del acto desviado, necesitándose de una psicología social de la reacción social. Los orígenes mediatos de la reacción social, por otro lado, importan que la teoría social debe ser capaz de explicar la función punitiva del Estado, sus intereses y los imperativos económicos y sociales de aquellos movimientos que busquen cambiar dicha función, necesitándose una economía politica de la reacción social. Ibid., pp. 308-311.

${ }^{24}$ BERGALLI, Op.cit., pp. 228.
} 
repetidamente a las corrientes examinadas en su obra, cual es que, a través de sus postulados, generalmente se termina desvinculando al hombre de la sociedad. ${ }^{25}$

Por otro lado, esta teoría postula que no basta con tener una actitud contemplativa frente a las crisis existentes en la teoría, en el pensamiento social y en la sociedad. De ahí que para ellos, esta nueva criminología deba plasmarse en una teoría normativa, y deba "ofrecer la posibilidad de resolver las cuestiones fundamentales, y de resolverlas socialmente" ${ }^{26}$ En esa línea, la teoría normativa que se formule a partir de los postulados de la teoría social de la desviación debe estar consagrada -como señalan los autores- a lograr la abolición de las desigualdades de riqueza y poder y, en especial, las desigualdades en materias de bienes y oportunidades. De no ser ese su norte, se corre el riesgo de incurrir en el correccionalismo, terreno en el cual la teoría social no debe caer, en la medida que todo correccionalismo, para ellos, está "indisolublemente ligado a la identificación del sujeto con la patología". ${ }^{27}$

\section{iii.- La criminología crítica en otros países}

Fue con su libro Criminología Crítica y Crítica del Derecho Penal, de 1982, que Alessandro Baratta se transformó, en uno de los exponentes más importantes de la criminología crítica en el ámbito continental. En la citada obra, este autor postula que la criminología crítica y la crítica del derecho penal deben constituir las bases sobre las cuales es posible elaborar una sociología jurídico-penal. ${ }^{28} \mathrm{~A}$ su juicio, esta construcción, importa la generación de una nueva ciencia, cuyo objeto debiera ser el estudio de los comportamientos normativos, que consisten en la formación y aplicación de un sistema penal dado, analizando las reacciones institucionales de los organismos oficiales de control social de la desviación, así como las reacciones no institucionales. ${ }^{29}$ Además, plantea que, tradicionalmente, la criminología crítica ha dirigido su atención al proceso de criminalización, habiendo individualizado los mayores problemas teóricos y prácticos de las relaciones sociales de desigualdad propias de la sociedad capitalista y ha perseguido como uno de sus objetivos principales, el extender la crítica del derecho desigual al campo del derecho penal. Sin embargo, señala que una de las principales tareas que debiera ocupar a los criminólogos críticos, es elaborar una "teoría materialista (económico-política) de la desviación, de los comportamientos socialmente negativos y de la criminalización, y trazar las líneas de una política criminal alternativa, de una política de las clases subalternas". ${ }^{30}$

\footnotetext{
25 TAYLOR/WALTON/YOUNG, Op. cit., pp. 316.

${ }^{26}$ Ibid.

27 Op. cit., pp. 318.

28 BARATTA, Criminología critica y crítica del Derecho Penal, Siglo veintiuno Editores, Buenos Aires, 2002. pp. 14 y ss.

29 Op. cit., pp. 14.

${ }^{30}$ Ibid., pp. 209.
} 
Morales - Las huellas de la criminología crítica...

Junto con lo anterior, Baratta sugiere la generación de un derecho penal minimo. En efecto, junto con recoger los pensamientos de la criminología crítica antes expuesta, los unió a la crítica al derecho penal realizada por la perspectiva abolicionista y abogó por un derecho penal mínimo y limitado por principios legales (tipicidad, irretroactividad, legalidad), funcionales (subsidiariedad, proporcionalidad) y personales (responsabilidad por el hecho), cuya función principal debe ser la de defender los derechos humanos. ${ }^{31}$ Esta obra, como señala Larrauri, surge como punto intermedio entre la discusión de los abolicionistas y los realistas de izquierda, ${ }^{32}$ y que como veremos, sin duda, fue una de las obras que influyó decisivamente en el pensamiento de Bustos.

Antes de analizar la influencia de los postulados de la criminología crítica en la obra del profesor Bustos, es necesario revisar las principales críticas que se han formulado a dicha corriente criminológica -algunas de las cuales el mismo apuntara- de manera de entender su influencia, no sólo en la obra de diversos autores, sino que en el mismo campo de la criminología.

iv.- Críticas y autocríticas

Es, sin duda, la catedrática española Elena Larrauri quien mejor ha logrado fusionar los principales cuestionamientos formulados a la criminología crítica, en especial aquellas dirigidas al libro La Nueva Criminología.

Una de las principales objeciones planteadas a dicha obra, fue que la nueva criminología no era precisamente nueva, toda vez que se limitaba a exponer teorías anteriores, sin elaborar una propia, la que -como señala Rock-, habría quedado en el útero. ${ }^{33}$

Además, se ha cuestionado a los autores de esa obra haber adoptado una concepción instrumental y funcionalista del derecho, dándose a entender que toda la ley y todo el control respondía a designios de la clase capitalista y que al Estado, por ende, le correspondía reprimir cualquier intento de oposición a esos intereses. ${ }^{34}$

Por otro lado, en relación a los postulados de corte marxista de la criminología crítica, algunos autores como Hirst acusan a esta corriente de contener un insuficiente análisis del marxismo, al postular la construcción de una teoría del delito con la concepción de los delincuentes como luchadores políticos donde la teoría marxista tradicional recogía una actitud más reaccionaria frente al sujeto desviado- y en que la meta de una sociedad sin el poder de criminalizar,

\footnotetext{
31 Vid. BARATTA, Principios del Derecho Penal Minimo en Criminología y Sistema Penal (Compilación in memoriam), Editorial B de F, Buenos Aires, 2004.

32 LARRAURI, Op. cit., pp. 198.

33 Op.cit., pp. 116.

${ }^{34}$ Ibid., pp. 122-123.
} 
aparece más cercana a las posturas anarquistas. ${ }^{35}$ Otros, por el contrario, le criticaron el hecho de exacerbar los postulados marxistas, al rechazar el resto de las perspectivas criminológicas y caer en el determinismo tradicionalmente adjudicado a los postulados marxistas. ${ }^{36}$ Además, se le objeta la dificultad de integrar teóricamente las corrientes marxistas con las sociológicas, considerando adicionalmente que los autores se preocuparon de descalificar estas últimas, llevando a desestimar el potencial subversivo y teórico de los planteamientos. ${ }^{37}$ Junto con lo anterior, se acusó a los nuevos criminólogos de lo que Rock llamó un "imperialismo epistemológico", donde no adoptar una concepción de la criminología desde una perspectiva marxista aparecía como una muestra de ignorancia y no de desacuerdo. ${ }^{38}$

En particular, en la línea del determinismo expuesto por Larrauri, los autores británicos Downes y Rock plantean que los criminólogos críticos apostarían a una "total interconexión" entre el delito y el capitalismo, siendo el conflicto de clases la forma, en vez de una de las formas de conflicto de las sociedades industriales. ${ }^{39}$ De ahí que, como postulan estos autores sea un error el abogar por la modificación del capitalismo y del problema criminal, toda vez que con la eliminación del primero, necesariamente debiera extinguirse el segundo, o al menos aminorarse sustancialmente todo aquel fenómeno delictual atribuible al modelo capitalista. ${ }^{40}$

Por otro lado, Downes y Rock, en una crítica formulada especialmente a los postulados de los norteamericanos Chambliss y Platt, antes expuesta, objetan la falta de permeabilidad de la teoría a otras manifestaciones político-económicas. En efecto, una de las principales falencias de los postulados de estos teóricos radica en que, para ellos, el capitalismo de Estados Unidos, es "el" capitalismo, que el crimen de Estados Unidos es "el" crimen, creyendo, por lo tanto, que en todas partes uno va encontrar más o menos lo mismo. ${ }^{41}$ De ahí que, como señalan, no hay modelos políticos económicos intermedios: la democracia social es una forma aminorada de capitalismo y el socialismo estatal una forma fallida del socialismo. ${ }^{42}$

Otra esfera de críticas de orden práctico radicó en que muchas de sus reflexiones son concebidas como derechamente improductivas. En ese sentido, se le reprocha a la criminología crítica el no hacerse cargo en definitiva del problema real. Así, como señala Cohen, la criminología de corte oficial siguió "haciendo lo

\footnotetext{
${ }^{35}$ Ibid., pp. 124-125.

36 Ibid., pp. 119-121.

${ }^{37}$ Ibid., pp. 142.

38 Ibid., pp. 127.

${ }^{39}$ DOWNES/ROCK, Op. cit., pp. 277.

40 Op. cit.

${ }^{41}$ Ibid., pp. 282.

${ }^{42}$ Ibid.
} 
Morales - Las huellas de la criminología crítica...

de costumbre", ${ }^{43}$ mientras que los primeros "no adoptaron los temas candentes del momento y se concentraron en temas como la delincuencia expresiva, más alejados de las preocupaciones prosaicas de la sociedad", ${ }^{44}$ De esta forma y sin perjuicio que la criminalidad en los años setenta iba en aumento, las nuevas teorías no se pronunciaron al respecto, y aún más, como denuncian algunos, al no producir investigaciones, "se quedaban en la mera denuncia de la investigación previa y de lo que sucedía y, en este último caso, con pocos datos sobre lo que efectivamente sucedía". 45

Por último, con el resurgimiento en los ochenta de los políticos neoconservadores, comenzaron las críticas desde esa perspectiva de derecha, las que buscaban obviamente terminar con el idealismo radical, reenfocando la criminología a una de corte actuarialista, calculadora y evaluadora de los riesgos, orientada crecientemente en la difícil situación de la víctima, en la prevención situacional y ambiental del crimen, y en programas enfocados a la comunidad. ${ }^{46}$

Muchas de las críticas antes señaladas hicieron rápidamente que los precursores de la criminología crítica iniciaran un período de análisis reflexivo y cambio de dirección en sus planteamientos, considerados por muchos como utópicos e impracticables. De ahí que, como señala Larrauri, se iniciara un período de "contrarreforma". En consecuencia, conceptos como el de "inseguridad ontológica, crisis existencial y de profunda inseguridad, prontamente entraron a las filas de los criminólogos críticos. Profunda contemplación, reanálisis y reflexión pública y privada se convirtieron en la orden del día". ${ }^{49}$

Dentro de esta contrarreforma de la criminología crítica, destacan la reevaluación de las posiciones frente al delito común, la negación del poder político de la delincuencia y la matización de las críticas formuladas al positivismo. ${ }^{50}$ Algunos de estos replanteamientos los encontramos en posteriores obras de Taylor, Walton y Young como aquella denominada La Criminología Crítica, y será sin duda éste último autor el más paradigmático de los criminólogos críticos que vivieron este proceso, especialmente al manifestar la necesidad de dedicar más

\footnotetext{
${ }^{43}$ COHEN, Footprints in the sand: A further report on Criminology and the Sociology of Deviance in Britain, en Against Criminology (1981), pp. 84, citado por LARRAURI, Op. cit., pp. 149.

${ }^{44}$ Ibid.

45 ANITUA, Op. cit., pp. 429.

${ }^{46}$ Sobre el surgimiento de estas políticas neocoservadoras y de la criminología actuarialista -o como la denomina Garland "Criminologías de la vida cotidiana"-; Vid. GARLAND, La Cultura del Control, Gédisa, Barcelona, 2005; O’MALLEY, Volatile and contradictory punishment en Theoretical Criminology 3, Sage, Londres, 1999; y WACQUANT, Las cárceles de la miseria, Manantial, Buenos Aires, 2004.

47 HIL, Facing Change: New directions for critical criminology en the early new millennium?, en Western Criminology Review 3, pp.8. Artículo en Internet http://wcr.sonoma.edu/v3n2/hil.html.

${ }^{48}$ LARRAURI, Op. cit., pp. 143 y ss.

${ }^{49}$ HIL, Op. cit. pp. 8. La traducción es de la autora.

${ }^{50}$ LARRAURI, Op. cit ., pp. 143.
} 
atención al delito común y a los estragos que éste causa en la clase obrera, a través de su artículo "Criminología de la clase obrera".

Esta revisión de la criminología crítica o "contrarreforma" postula, entre otros puntos, que efectivamente el delito es un problema real, que va en aumento y es grave, que el delito sí tiene víctimas -pertenecientes generalmente a la clase trabajadora- y donde a su vez son éstas últimas las que más cometen delitos. Además, descarta la postura anti-criminalización o a favor de una sociedad en que no exista la necesidad de criminalizar, admitiendo la aplicación del derecho penal para castigar las vulneraciones de los derechos fundamentales, entendiéndolo ya no desde una concepción instrumental, y advirtiéndose la necesidad de controlar determinadas actividades en toda la sociedad. ${ }^{51}$

Young, posteriormente, endureció aun más su discurso, especialmente frente a la presencia de los neoconservadores de la "ley y el orden", planteando la necesidad de no dejar abandonado el terreno a estos últimos, debiendo asumir la criminología la tarea de luchar contra en delito, pudiendo utilizarse en esta lucha la policía, el sistema penal y debiendo elaborar un programa de control del delito mínimo, democrático y multifuncional. ${ }^{52}$ De ahí que a partir de estas declaraciones, autores como él pasaron a ser conocidos como "realistas de izquierda" y propició el resurgimiento de las corrientes abolicionistas, representadas en las obras de Christie, Mathiesen, Bianchi y Hulsman.

Así entonces, con preguntas relativas a la esencia de la criminología crítica y respuestas diversas a dichos debates, hoy es difícil rastrear el estado de discusión en la materia. Sin duda, no dejan de sorprender los cambios que han tenido las posturas basales de la criminología crítica, donde cabe incluso preguntarse qué de marxista queda en ella. Estos cambios pueden ser el fruto de la maduración y reflexión de sus ideas primarias, ligadas a las vertiginosas transformaciones que ha sufrido la sociedad en las últimas tres décadas. Sin embargo, una de las críticas que se agudiza con estas reformulaciones es aquélla que observa que la aceptación de categorías tales como "crimen", "el problema del delito", "estadísticas delictuales" o sin duda la frase contemporánea de Young de "tomarse el delito en serio", importa que se asuman y absorban ciertas formas de pensar acerca del delito, las que se asemejan bastante a las posturas positivistas férreamente resistidas por los criminólogos críticos. ${ }^{53}$ De esta forma, despierta dudas el que pueda hablarse de una nueva criminología o incluso de una de corte marxista si no se realiza el ejercicio crítico más básico respecto de las herramientas conceptuales utilizadas. ${ }^{54}$ En ese sentido, como postula Muncie, la cuestión del crimen y otras categorías,

\footnotetext{
51 Op. cit., pp. 188.

${ }^{52}$ Vid. LEA,/YOUNG, ¿Qué hacer con la ley y el orden? Editores del Puerto, Buenos Aires, 2001.

${ }^{53}$ HIL, Op. cit., pp.11.

${ }^{54}$ Ibid.
} 
Morales - Las huellas de la criminología crítica...

debieran ser el punto de inicio de cualquier análisis criminológico. ${ }^{55}$ Éste fue sin duda, como veremos en los próximos párrafos, un punto de preocupación para Bustos, y en efecto, constituiría una de sus principales críticas a dicha corriente.

\section{v.- Bustos y la criminología crítica}

Un breve análisis de los postulados de la criminología crítica, lo encontramos en el tomo I de sus Obras Completas, en el capítulo dedicado a analizar el resurgimiento de la política criminal. ${ }^{56}$ En él, Bustos hace alusión a la importancia del funcionalismo heredero del pensamiento de Durkheim -en la medida que representó un camino alternativo al del positivismo- y destaca la relevancia del labelling aproach, en especial en la investigación de los procesos de etiquetamiento del criminal. Luego, revela la trascendencia de los postulados de la criminología crítica, haciendo alusión por cierto, a la obra de Taylor, Walton y Young, señalando que la misma, a través de "un proceso dialéctico busca la realidad de los procesos, considerando un individuo determinado en sus relaciones con otros, con las clases y con la totalidad social y natural". ${ }^{77}$ Más aun, a partir de la anterior afirmación, argumenta que ésto lleva a considerar al individuo frente al derecho penal e investigar el proceso que se da entre los dos, llevando necesariamente, a "la consideración del contexto económico, social y político en que tal proceso tiene ocurrencia." 58

En la citada obra, además expone que, dentro de la criminología crítica, se han ido perfilando distintas posiciones, permitiendo el replanteamiento de la tesis del abolicionismo penal y de la propia criminología radical, dando origen al "realismo criminológico" o "realismo de izquierda", como ya se explicara en párrafos anteriores. En relación a los abolicionistas, los acusa de tener una posición reductora al trabajar con una concepción de Estado inexistente, limitada sólo a los aparatos de control, sin reconocer a la sociedad civil. Además, les critica el hecho de desmontar, a través de sus postulados, las garantías propias del derecho penal, en circunstancias que el derecho sancionador, selectivo y discriminador seguirá existiendo en la medida que continúen las estructuras del Estado que le dan vigencia, operando sin ninguna garantía. ${ }^{60}$ Respecto del realismo de izquierda, Bustos formula una interesante crítica que se acerca a aquella expuesta por Hil y desarrollada anteriormente. En efecto, él observa que, si bien esta contrarreforma se ha alejado del abolicionismo -acercándose al minimalismo y entendiendo que el derecho intenta precisamente proteger a los desposeídos-, en esta reformulación se continúa otorgándole un "carácter categorial al delito", no

55 MUNCIE, Reassessing competing paradigms in contemporary criminological theory, en WALTON/YOUNG (ed.) The new criminology revisited, Macmillan, Londres, 1998, pp. 232.

${ }^{56}$ BUSTOS, Op. cit., Tomo I, pp. 289 y ss.

${ }^{57}$ Op. cit., pp. 309.

${ }^{58}$ Ibid., pp. 309-310.

${ }^{59} \mathrm{Ibid}$, pp. 310.

${ }^{60}$ Ibid., pp. 311. 
considerándolo como un proceso de criminalización y retornando poco a poco, a todas aquellas características del derecho penal y control penal estrictamente tradicional. ${ }^{61}$ Además, agrega que estas reformulaciones ya habían dejando en claro que "la ley penal no es igualitaria, que la igualdad es un postulado", ${ }^{62}$ cuestiones que -a su juicio- se estarían pasado por alto.

En esa línea recordemos que, si bien los autores de La Nueva Criminología plantearon la necesidad de que los postulados de la criminología crítica se vieran plasmados en una teoría normativa -formulada a partir de los postulados de su teoría social de la desviación, que debiese estar consagrada a lograr la abolición de las desigualdades de riqueza y poder y, en especial de las desigualdades en materias de bienes y oportunidades-, lamentablemente en sus escritos, fundamentalmente los ulteriores, hicieron suyos aquellos conceptos normativos que precisamente son producto y reflejo de esa sociedad capitalista, generadora de aquellas desigualdades que tanto reprocharon.

En efecto, es en relación a este último punto que cobra especial relevancia la obra de Bustos, toda vez que a través de los postulados de la criminología crítica, él logra repensar una teoría normativa, en especial un nuevo derecho penal, que se haga cargo de esas desigualdades y que, como él plantea, sea fruto de una revisión crítica del proceso de criminalización, desde la creación de la norma, hasta su aplicación en el proceso y posterior cumplimiento de la condena. ${ }^{63}$ Así, para él, la criminología debe surgir como una "disciplina crítica respecto del Derecho Penal" y a partir de ella deben sentarse las bases de una nueva teoría normativa. ${ }^{64}$

En resumen, se puede plantear que, si bien Bustos es, sin duda, un seguidor de la criminología crítica -en la medida que ésta última constituye el fundamento principal de la necesidad de repensar el derecho Penal a partir de sus postulados-, él asume más bien una postura intermedia, más cercana, por ejemplo, a lo que fueran los pensamientos de Baratta. Esto, pues si bien para él el derecho penal es una representación del poder político del Estado, que se manifiesta de manera desigual, estima que éste no debe ser abandonado, sino más bien revisado a la luz de los principios de la criminología crítica, de manera que el mismo se reconfigure y opere como corrector de dichas desigualdades en la esfera de la justicia penal. Así, Bustos se dice partidario de un "derecho penal de alternativas", buscando que el propio sistema se abra a soluciones diferentes no necesariamente penales como son la reparación y la mediación. ${ }^{65}$

\footnotetext{
${ }^{61}$ Ibid., pp. 311-312.

62 Ibid., pp. 312.

${ }^{63}$ Ibid., pp. 336.

${ }^{64}$ Ibid., pp. 339.

${ }^{65}$ Ibid., pp. 418.
} 
Morales - Las huellas de la criminología crítica...

\section{La reformulación de la dogmática a partir de los postulados de la criminología crítica}

El profesor Bustos plantea que tres han sido los pilares básicos del derecho penal moderno que deben ser revisados a la luz de los postulados de la criminología crítica. A saber, estos principios son: el de la igualdad, el de la libertad y el de la justicia; y que, como veremos más adelante, están en directa conexión con la teoría de la norma jurídica, la teoría de la pena, y la teoría del bien jurídico, todas las cuales deben ser revisadas bajo dicha óptica. ${ }^{66}$

\section{La revisión de los principios del derecho penal moderno}

El primer principio básico del derecho penal moderno es el de la igualdad, y a partir de éste han surgido las construcciones teóricas que lo sustentan. Como argumenta Bustos, con el simple hecho de la eliminación de todo el sistema de subordinaciones personales del Antiguo Régimen se pretendió, a su vez, que se eliminaría todo criterio discriminatorio frente a la autoridad, frente al control y que, por tanto, todos los sujetos serían ahora iguales ante la ley. ${ }^{67}$

Para rebatir este argumento, plantea Bustos que ni siquiera es necesario recurrir a la tesis de Marx de que la justicia es una justicia de clases y que, por lo tanto, las leyes penales como expresión del poder de una clase no pueden recaer sobre ella, sino que sobre la clase sometida. Basta con recurrir a la teoría del etiquetamiento o labelling para entender que el proceso de criminalización -como fuese planteado en párrafos anteriores- es en sí mismo desigual en la medida que el proceso de definición y selección de los desviados es realizado por los grupos de poder. Es decir, la determinación de quién es desviado y de quiénes deben entrar, en consecuencia, al sistema penal, depende exclusivamente de quien genera las normas, esto es, los grupos de poder. ${ }^{68}$ En efecto, como lo han demostrado numerosos estudios del sistema penal y del perfil de los sujetos a dicho control, los que están en las cárceles en su mayoría son representantes de los estratos sociales más bajos, especialmente jóvenes, que nada tienen que ver con las clases dominantes. ${ }^{69}$

De esta forma, para Bustos, la igualdad ante ley no es más que un axioma de la lógica abstracta, no pudiendo ser el punto de partida de una construcción jurídico penal, sino que más bien un programa a alcanzar. Así para él, sólo "el

\footnotetext{
${ }^{6}$ Op. cit.,Tomo II, pp. 9 y ss.

${ }^{67}$ Ibid., pp. 10.

${ }^{68}$ Ibid.

${ }^{69}$ Un ejemplo de lo anterior, lo encontramos en la obra del norteamericano Jeffrey Reiman "The rich Get Richer and The Poor Get Prison", en la que argumenta que el sistema de justicia norteamericano ha creado una imagen engañosa del criminal como la de un hombre, joven, negro y perteneciente a la clase obrera. Así, para Reiman, el citado sistema de justicia genera y reproduce crimen, criminalizando el uso de la droga, manteniendo prisiones que generan reincidentes, negándose a hacerse cargo de las inequidades sociales y económicas y estigmatizando a los criminales.
} 
reconocimiento de que el derecho penal no es igualitario, permitirá la construcción de un derecho penal materialmente garantista". ${ }^{70}$

El segundo principio básico del derecho penal moderno es el de la libertad de los sujetos. Conforme este principio, todos los sujetos son igualmente libres y capaces de determinarse por el valor que está recogido en las normas jurídicas. De esta forma, los sujetos pueden elegir dado que tienen capacidad de ajustarse o no al contenido de las normas. $\mathrm{Y}$ es precisamente a partir de este principio dogmático que se construyó el principio de culpabilidad. Así, el castigo se fundamenta en que los sujetos pueden ser declarados culpables porque tienen capacidad de reflejarse y ajustarse o no al valor recogido en las normas jurídicas. ${ }^{71}$

Para rebatir este argumento, Bustos plantea nuevamente que ni siquiera es necesario recurrir a aquellos postulados marxistas de que el cuerpo social está dividido en varias clases antagónicas que tienen sus propios intereses y valores, y que, por lo tanto, lo dotan de significados y contenidos distintos, no pudiendo hablar de un interés social o un valor social único. Sino que basta con recurrir a las teorías de las subculturas y del conflicto para explicar que el postulado de la libertad es más bien pura ideología. En efecto, conforme la primera de estas explicaciones sociológicas, derivada de la asociación diferencial, cada grupo tiene sus propias formas de aprendizaje y, por lo tanto, sus propios intereses y valores. Por otro lado, la teoría del conflicto plantea que el sistema social se mueve por el conflicto procesal entre los grupos fundamentales que lo componen, imponiendo cada uno sus intereses y valores al momento de triunfar. De ahí entonces que en realidad el derecho penal asume valores e intereses que no están presentes o reconocidos en todos los grupos sociales, y que, por ende, el principio de culpabilidad provenga más bien de una construcción unitaria, absoluta y abstracta, incapaz de reconocer los diferentes contenidos de los intereses y valores. ${ }^{72}$

Un tercer principio básico del derecho penal moderno es el de justicia. Conforme este principio, la dogmática construye un derecho penal justo, en que los hechos realizados se valoran en su justo valor y, por lo tanto, la pena aparece como la medida justa al desvalor del delito. Para rebatir este argumento, una vez más, no es necesario recurrir a la injusticia de la explotación de una clase por otra afirmando que el derecho, y específicamente el derecho penal, constituye una forma más de explotación y fruto, por ende, de injusticias al servicio de las grandes mayorías, y que la pena constituye una forma de regulación de la disciplina del trabajo y del mercado, sino que basta con recurrir a la teoría psicoanalítica de la criminalidad y a la teoría de la anomia. Así, conforme a la primera, el delito y el delincuente no son sino expresión de la necesidad afincada en las frustraciones y deseos del inconsciente social, siendo el delito y el delincuente sus chivos expiatorios, mientras que conforme la segunda visión estructural funcionalista, el

\footnotetext{
${ }^{70}$ BUSTOS, Op. cit., pp. 11.

${ }^{71}$ Op. cit., pp. 11-12.

${ }^{72}$ Ibid., pp.12.
} 
Morales - Las huellas de la criminología crítica...

delito y el delincuente no son sino una resultante social que cada sistema produce y son, por tanto, producto de determinadas funciones sociales. De ahí que, conforme a ambas posturas, no cabría hacer la distinción entre bien y mal, entre buenos y malos, como lo fundamenta el derecho penal justo, y donde las "garantías no tienen que estar fundadas en una teoría sobre el merecimiento sobre lo que valen de por sí los hechos (distinción sobre buenos y malos), sino de que el derecho penal produzca el menor daño posible en los sujetos, pues no hay buenos y malos, sino sólo personas en conflicto social constante dentro del sistema". ${ }^{73}$

Como se observa, para Bustos, estos tres principios que constituyen los pilares del derecho penal moderno se fundamentan en axiomas o ideologías que no tienen reconocimiento en la realidad, entendiendo que el derecho penal y estas garantías -construidas como limitantes de la intervención del Estado- no pueden ser concebidos prescindiendo de la realidad en que se mueven los ciudadanos a los cuales se aplica. De ahí que, como precisa, de otro modo el derecho penal "no pasa de ser una pura ficción o los buenos pensamientos de unos buenos juristas". ${ }^{74}$ Es por esto que necesariamente dichos principios deben ser reevaluados, como lo hiciera la criminología crítica, explícitamente con el concepto de la igualdad, entendiendo que el sistema penal es por esencia desigual, de manera de dotar de contenido efectivo a aquellas garantías que operan como límite a la intervención punitiva del Estado.

A partir de la reformulación de estas garantías es que, como veremos a continuación, Bustos plantea el desafío de analizar críticamente las bases estructurales de la dogmática penal plasmadas en las teorías de la norma jurídica, la teoría del bien jurídico y de la pena.

\section{Revisión de la teoría de la norma jurídica}

Como sabemos existen distintas posiciones que dan sustento a la teoría de la norma jurídica. Efectuando un breve repaso a sus planteamientos más importantes, para efecto de contextualizar los postulados de Bustos, encontramos en primer lugar la teoría monista, que entiende que el derecho, esto es el conjunto del ordenamiento jurídico, estaría constituido por imperativos -siendo estos prohibiciones y mandatos- donde todo el resto sería accesorio. Dicho concepto fue criticado por Binding ${ }^{75}$, quien, a través de la teoría dualista, observa que dicha visión deja de lado todo el problema de los derechos subjetivos y, por ende, que la norma y en general el ordenamiento jurídico está constituido no sólo por prohibiciones y mandatos, sino que también por autorizaciones, recogiendo, por lo tanto, la esfera de los derechos subjetivos. Luego, una tercera visión sería

\footnotetext{
73 Ibid., pp.13.

${ }^{74}$ Ibid, pp. 330.

75 Vid. BINDING, Die normen und ibre Übertretung,Tomo I, Leipzig, 1916, citado por BUSTOS, Op. cit., Tomo I, pp. 27.
} 
entregada por Kelsen ${ }^{76}$ quien, retornando al concepto monista -aunque desde una perspectiva distinta-, plantea que lo único que tiene sentido en la regla jurídica es la sanción, y de ahí que todas las normas sean de carácter sancionatorio. De esta forma, para Kelsen lo que importa es el Estado y no los individuos, manifestando su actividad en normas sancionatorias, entendidas estas últimas como la acción del Estado desde una perspectiva coactiva. Desde otra perspectiva distinta, Hart ${ }^{77}$ plantea que en el ordenamiento jurídico no sólo hay reglas jurídicas que valoran el acto, sino también objetos, cosas, relaciones y organizaciones. De esta forma, la norma debe recoger dicha complejidad, no pudiendo restringirse a visiones monistas o dualistas o de la sanción. También en esta línea encontramos la obra de Calliess $^{78}$, para quien la norma es un proceso comunicativo o interactivo, compuesto por determinaciones tanto del sujeto como del otro interviniente en que la norma resulta "un complejo dialogal". 79

Tomando en cuenta estas posturas, y a partir de una revisión crítica de la teoría de la norma, Bustos, siguiendo el camino de estos últimos autores, plantea su rechazo a las teorías monistas y dualistas, argumentando que la estructura del ordenamiento jurídico y la norma es aún más compleja, particularmente en relación a su génesis o legitimación. Así, para él, la norma "no surge en virtud de un fiat metafísico y tampoco como en el Estado absoluto, por la sola voluntad del soberano, sino que la norma aparece en un Estado de derecho en razón de un proceso legitimante, que, según sean las posiciones doctrinarias, puede tener por base el consenso de los ciudadanos, el enfrentamiento de los grupos del poder (para la teoría del conflicto) o bien la confirmación de la ideología dominante o hegemónica del poder político". ". Así, para él, el punto de partida es la relación social en que los sujetos participan para la satisfacción de sus necesidades y por lo mismo generan intereses contrapuestos, dando origen al conflicto social. De esta forma, la norma tiene su origen en la base social y es producto de los procesos interactivos que tienen lugar en su seno, y que en un Estado Democrático de Derecho son "producto de la discusión participativa en que la hegemonía alcanzada está dispuesta en el futuro a aceptar su revisión". 81 Luego, la norma jurídica "interviene en el conflicto social", de ahí que su estructura sea de "carácter dialogal" o dialéctico, ya que implica una interacción objetiva y especialmente simbólica entre sujetos o, como plantea Bustos, de "significaciones". ${ }^{82}$ A partir de esta afirmación, él sostiene que necesariamente debe hacerse una revisión total de las posturas dogmáticas referidas a los elementos del delito, esto es, la teoría de la

\footnotetext{
${ }^{76}$ Vid. KELSEN, Hauptprobleme der Staatsrechtslehre, Tübingen, 1923, citado por BUSTOS, Ibid, pp. 28.

77 Vid. HART, Derecho y moral, Depalma, Buenos Aires, 1962, citado por BUSTOS, Ibid.

78 Vid. CALLIESS, Theorie der strafe im demokratischen und sozialen Rechtsstaat, Frankfurt am Main, 1974, citado por BUSTOS, Ibid. , pp. 29

79 Ibid, pp. 28.

${ }^{80}$ Ibid., pp. 29.

${ }^{81}$ Ibid., pp. 363.

82 Ibid., pp. 198.
} 
Morales - Las huellas de la criminología crítica...

causalidad, teoría de la acción, teoría de la tipicidad y la teoría de la antijuricidad, toda vez que están indefectiblemente unidas a la teoría de las normas.

Considerando lo anterior, a la luz de los postulados de la criminología crítica, es posible dotar de un contenido distinto del tradicionalmente otorgado a las normas jurídicas, de manera que ellas tengan su origen en el entramado social y sean, a su vez, reflejo de las interacciones que se producen en la sociedad. Sin embargo, como el mismo Bustos argumenta, si bien las normas son reflejo de estas interacciones sociales, no pueden ser explicadas por sí mismas en su contenido, sino que para ello es necesario buscar el "eje de referencia de la regla jurídica, que es justamente el bien jurídico". ${ }^{83}$

\section{Revisión de la teoría del bien jurídico}

Tradicionalmente, los debates teóricos entorno al bien jurídico pueden ser analizados desde el punto de vista de su naturaleza y desde la perspectiva de su titular. Así, en relación a su naturaleza, podemos encontrar dos tipos de criterios: el trascendental y el inmanente; y a su vez dentro de la dirección trascendental, podemos encontrar justificaciones desde la perspectiva iusnaturalista y de política criminal, mientras que desde la perspectiva de su titular, encontramos aquella posición que hace residir la titularidad del bien jurídico en el Estado y aquélla que la decanta en el individuo. Haciendo un breve repaso de estas concepciones de manera de situar el debate, encontramos en primer lugar desde la visión trascendental, la posición iusnaturalista que argumenta que el Estado, con el delito, protege ciertos objetos, esto es bienes jurídicos que surgen de la naturaleza de las cosas, como son la vida, el honor, la salud, etc. Luego, la visión política criminal desarrollada por Von Liszt plantea que los bienes jurídicos no son bienes del derecho, sino de los hombres, y que, por tanto, al derecho sólo le cabe reconocer estos intereses, que aparecen para el individuo en su actividad social. ${ }^{84}$ En este sentido, en ambas direcciones trascendentales, los bienes jurídicos surgen más allá del derecho y, por lo tanto, solo cabe la tarea de reconocerlos. ${ }^{85}$ Por otro lado, en el criterio de la inmanencia desarrollado por Binding ${ }^{86}$, los bienes jurídicos son inmanentes a la norma y, por tanto, cada norma tiene y determina totalmente el bien jurídico, en una suerte de criterio teleológico. Ahora bien, desde la perspectiva de su titular, encontramos la posición de Binding y Roco ${ }^{87}$, donde la titularidad del bien jurídico recae en el Estado; y la del ya citado Von Liszt, para quien el titular del bien jurídico es el individuo considerado socialmente. ${ }^{88}$

\footnotetext{
83 Op. cit., Tomo II, pp. 83.

${ }^{84}$ VON LISZT, Tratado de Derecho Penal, Tomo II, $2^{\circ}$ Ed, Editores Reus, Madrid, 1927, pp. 2.

${ }^{85}$ BUSTOS, Op. cit., Tomo I, pp. 30.

${ }^{86} \mathrm{Vid}$. BINDING, Op. cit., citado por BUSTOS, Ibid.

${ }^{87}$ Vid. ROCCO, L'oggetto del reato e Della tutela giuridica penale, en Opere Giuridiche, Vol. 1, Roma, 1932, citado por BUSTOS, Ibid.

${ }^{88}$ VON LISZT, citado por BUSTOS, Op. cit., pp. 31
} 
Conforme postula Bustos, si se consideran conjuntamente los criterios de la inmanencia con aquel que entrega la titularidad del bien jurídico al Estado, se llega a círculos viciosos de nunca acabar. Así, si entendemos que el bien jurídico es inmanente a la norma, quiere decir que es necesario, por lo tanto, encontrar su contenido en ella (la norma), la que a su vez no se podría explicar en sí misma, sino en referencia a algo, esto es, el bien jurídico, argumentación que, desde luego, es tautológica. Por otro lado, si se recurriera al criterio de la titularidad por parte del Estado del bien jurídico, se llegan a absurdos similares, toda vez que si el Estado es su único titular, quiere decir que es él quien lo fija, y si lo fija a través de la norma, nuevamente se llega a la misma solución de nunca acabar. De ahí que Bustos, como la mayoría de la doctrina, se incline por la teoría trascendental de Von Liszt, donde el bien jurídico sólo puede referirse a una sociedad existente y real. $^{89}$

En consecuencia, para Bustos, considerando que la norma jurídica tiene su origen en la base social, constituyéndose en un producto de los procesos interactivos que tienen lugar en su seno, los bienes jurídicos deben ser concebidos como "relaciones sociales concretas". 90

De esta forma, considerando el enfoque de la criminología crítica, la conceptualización de los bienes jurídicos como relaciones sociales concretas implica identificar la posición de las personas dentro de la realidad social y por lo tanto permite "comprobar si la penalización de una conducta significa discriminación de personas, el favorecimiento de situaciones de desigualdad, la protección de una determinada concepción del mundo y su imposición mediante conminación penal, [o] la protección de algún fundamentalismo de alguna clase". ${ }^{91}$ De ahí que una teoría crítica del bien jurídico deba poner en relieve precisamente el carácter "discriminatorio e injusto del derecho penal".

\section{Revisión de la teoría de la pena}

Como sabemos, la teoría de la pena ha sido desarrollada por muchos y prestigiosos autores. De ahí que, a continuación, sólo haré una breve exposición de las principales construcciones, para luego adentrarme en la visión de Bustos acerca de la misma.

Las principales teorías son las absolutas, las relativas y las posiciones mixtas o eclécticas. Las teorías absolutas derivan de los pensamientos filosóficos de Kant y Hegel, donde para el primero, el único fundamento de la pena es la retribución a la culpabilidad del sujeto, operando como un imperativo categórico, esto es, imponiéndose al sujeto porque ha delinquido; mientras que para el segundo, la

\footnotetext{
${ }^{89}$ Ibid., pp. 31.

${ }^{90}$ Ibid., pp. 364.

${ }^{91}$ Ibid.

${ }^{92}$ Op. cit., Tomo II, pp. 18.
} 
Morales - Las huellas de la criminología crítica...

pena es la negación de la negación del derecho y, por lo tanto, según sea la intensidad de la negación, será la nueva negación de la pena. En la misma línea, Carrara $^{93}$ postula que la pena sólo tiene un fin en si misma, y no en fines utilitarios, ya que su fin no es otro que el restablecimiento del orden externo de la sociedad; mientras que Binding plantea que la pena es "la conservación del señorío del derecho a través del doblegamiento del criminal bajo la coerción jurídica", y por lo tanto, de lo que se trata es justamente de confirmar simplemente el poder del derecho, siendo para ello necesario el sometimiento por la fuerza del culpable. ${ }^{94}$ En el mismo sentido, Mezger ${ }^{95}$ sostiene que la pena es una irrogación de un mal que se adecua a la gravedad del hecho cometido en contra del ordenamiento jurídico; mientras que para Welzel ${ }^{96}$, la pena aparece como un mal para el sujeto culpable, basado en una retribución justa, esto es que la persona sufra lo que sus hechos valen. ${ }^{97}$

Como se observa, en todos estos casos no se reconocen fines más allá de la sola imposición de la pena por el hecho de haber cometido el delito y, por lo tanto, la pena es justificada retrospectivamente como un fin en sí misma. La importancia de estos razonamientos y, sin duda, una de sus mayores fortalezas es que, a pesar de su severidad, impone un límite de proporcionalidad implícita en el castigo y afianza la idea del castigo justo. Sin embargo, una de las críticas fundamentales a esta teoría es que, a través de la misma no es posible dar una respuesta satisfactoria a la pregunta del por qué castigar, pues su respuesta sobre la base de construcciones metajurídicas -como plantea Lacey- siempre nos deja con la sospecha que la retribución no puede ser distinguida claramente de la venganza o de la poco atractiva afirmación de que, de alguna forma, dos males conforman un bien. $^{98}$ Desde otro punto de vista, Bustos plantea que esta concepción de la pena está íntimamente ligada a una determinada concepción de Estado, particularmente a la del Estado no intervencionista, o de mero guardián, como se observa en los escritos de Nozick. ${ }^{99}$ Así, conforme la construcción racionalista de este último autor, cualquier otra función que vaya más allá de simplemente conservar el pacto social, no le corresponde al Estado, y de ahí a que de manera de asegurar la

${ }^{93}$ Vid. CARRARA, Programa de derecho criminal, Vol. II, Temis, Bogotá, 1972, citado por BUSTOS, Op. cit., Tomo I, pp. 119.

${ }_{94}$ BINDING, Normen, I, pp.420, citado por KAUFMAN, Teoría de las normas, Ediciones Depalma, Buenos Aires, 1977, pp. 20.

95 Vid. MEZGER, Strafrecht, Berlin y München, Duncker y Humblot, 1949, citado por BUSTOS, Op. cit., pp. 120.

${ }_{96}^{6}$ Vid. WELZEL, Derecho Penal Alemán, Editorial Jurídica de Chile, Santiago, 1976 citado por BUSTOS, Ibid.

${ }^{97}$ Una reformulación relativamente reciente de la teoría retribucionista la encontramos en la obra de Von Hirsch Censura y castigo, para quien el castigo supone la imposición de una privación (sufrimiento) por la supuesta realización del daño una forma tal que el castigo exprese desaprobación (censura) de la persona castigada por su pensamiento. Vid. VON HIRSCH, Censurar y castigar, Trotta, Madrid, 1998.

${ }^{98}$ LACEY, State Punishment. Politics Principles and community values, Routledge, Londres, 1988, pp. 26.

${ }^{99}$ Vid. NOZICK, Anarquía, Estado y Utopía, Editorial Fondo de Cultura Económica, Buenos Aires - México - Madrid, 1991. 
autoridad del Estado como tal, se espere que todo ciudadano sepa que será juzgado por el mal cometido y que la medida de ese mal será la medida de esa pena. ${ }^{100}$ Por otro lado, y conforme una visión desde la perspectiva crítica, la posición de las teorías absolutas resultan débiles, especialmente si se entiende que la mejor forma de respetar la libertad de los individuos es a través de la intervención mínima del Estado, toda vez que, como señala Bustos, "el sistema mismo provoca desigualdades o disfuncionalidades que atentan contra la libertad de los ciudadanos y que sólo se pueden corregir o paliar mediante la intervención del Estado". ${ }^{101}$

Luego encontramos las teorías relativas o de la prevención, que justifican la pena desde una perspectiva utilitarista o prospectiva. En primer lugar encontramos la prevención general, sustentada, entre otros, por Bentham ${ }^{102}$ y Feuerbach ${ }^{103}$, que postulan que la función de la pena es la de prevenir en forma general el delito ya sea positiva o negativamente. Para los precursores de la prevención general positiva, la pena tiene la función de reforzar la fidelidad o confianza de los ciudadanos al orden jurídicamente constituido, mientras que para los precursores de la prevención general negativa, la pena cumple el fin de intimidar o disuadir a los ciudadanos mediante el ejemplo o amenaza de la pena.

Sin describir en mayor detalle los postulados teóricos de la prevención general, y entrando derechamente al análisis crítico de esta teorías, encontramos que una de las objeciones más fuerte que se le formula, es que la prevención general utiliza a los individuos como instrumentos para la consecución de un fin social, más que un fin en sí mismos, de ahí que los individuos puedan ser sacrificados en atención a este propósito dominante, llegándose incluso a justificar el castigo de los inocentes, con el objeto de lograrlo. Por otro lado, para que el efecto preventivo general se cumpla, es necesario que exista una creencia general en la realidad de la amenaza, existiendo siempre el riesgo, en la práctica, que las personas descubran tal fin y, por ende, que el sistema se deslegitime. ${ }^{104}$ Desde otra perspectiva, Bustos señala que esta construcción parte de la base de Estados liberales, caracterizados por su mínima actividad coercitiva, cuestión que por un lado no sería aplicable dentro de los parámetros actuales de los Estados capitalistas y que, por otro lado, como planteara Roxin, deja sin aclarar el ámbito de lo punible. ${ }^{105}$ Además, el insistir en los límites de la eficacia preventivo general puede llevar a que, como plantea Bustos, para aumentar dicha eficacia, el Estado democrático se llegue a transformar en un Estado "puramente policial". ${ }^{106}$

\footnotetext{
100 BUSTOS, Op. cit., Tomo I, pp. 120.

101 Op. cit., pp. 121.

102 Vid. BENTHAM, Obras selectas, Tomo II, Librería el Foro, Buenos Aires, 2007.

103 Vid. FEUERBACH, Tratado de Derecho Penal común vigente en Alemania, Buenos Aires, 1989.

104 LACEY, Op. cit., pp. 29.

105 BUSTOS, Op. cit., pp. 123.

106 Op. cit., pp. 125.
} 
Morales - Las huellas de la criminología crítica...

Luego encontramos las teorías de la prevención especial, como aquella expuesta por Von Liszt, donde la pena es concebida como un instrumento para evitar que el infractor vuelva a delinquir. ${ }^{107}$ Así, dentro de estas visiones utilitaristas -muchas de ellas desarrolladas desde la perspectiva criminológica positivistaencontramos aquéllos que defienden la visión que la pena debe tener el fin de corregir a los infractores, esto es positiva, y aquellos que postulan que la pena debe tener la función negativa de neutralizar o incapacitar al sujeto infractor de la sociedad. Para ellos, ni el castigo ni la amenaza tienen sentido, sino que "de lo que se trata es de corregir, enmendar o rehabilitar; siempre que ello sea posible, si no de inocuizar". ${ }^{108}$

Nuevamente, sin entrar a un análisis pormenorizado de sus postulados, encontramos que uno de los mayores aportes de la prevención especial es el de haber puesto el acento en el individuo, considerándolo como tal en sus particularidades, no refiriéndose, por lo tanto, a construcciones metajurídicas o sociales difusas. Sin embargo, la prevención especial debe ser objeto de los mismos cuestionamientos formulados a la prevención general, en el sentido que con esta justificación se está instrumentalizando al individuo para los fines del Estado, perdiéndose el respeto a su dignidad. En particular en relación a esta última línea argumental, Roxin se pregunta sobre el fundamento de la legitimación del Estado para adoptar tales medidas, y de subyugar a una minoría, donde aparece como insuficiente la fundamentación según la cual estas personas deben ser educadas o deben vivir de determinada manera, por el sólo hecho de ser molestas o incómodas para la mayoría. ${ }^{109}$ Por otro lado, la prevención especial positiva, especialmente en su dimensión rehabilitadora, ha sido puesta en jaque a partir de los postulados del "Nothing Works". 110 De ahí que, si bien los Estados correccionalistas de mediados del siglo pasado generaron una serie de estudios e investigaciones entorno a la real eficacia de la rehabilitación a través de programas de tratamiento que incluían consejerías, grupos de trabajo y entrenamiento, psicoterapia farmacológica, llegando incluso a medidas extremas como el electroshock, hasta el día de hoy existe muy poca evidencia empírica de que aquellos métodos hayan tenido algún impacto en reformar a los infractores. ${ }^{111}$ En esa misma línea, Bustos argumenta que tal fin se enlaza, sin duda, con cuestiones prácticas, ya que el tratamiento requiere necesariamente de enormes recursos para efectos de contar con los establecimientos adecuados para llevarlo a cabo. Así, incluso para los países en desarrollo, el tratamiento generalmente quedará reducido para un grupo pequeño de sujetos y, como señalamos, aun en esos casos habrá dudas en cuanto a la eficacia y posibilidad real de disminuir la reincidencia. ${ }^{112}$

\footnotetext{
107 VON LISZT, Op.cit., pp. 6.

108 BUSTOS, Op. cit., pp. 127.

109 ROXIN, Problemas básicos de Derecho Penal, citado por BUSTOS, Op. cit. pp. 128.

110 Término utilizado por Martinson, y que refleja el ánimo escéptico de los años 70’ frente a la utilidad de las prácticas penales correccionalistas que buscaban rehabilitar a los infractores.

${ }^{111}$ LACEY, Op. cit., pp. 30 y 31.

112 BUSTOS, Op. cit., pp.129.
} 
Como una forma de respuesta a las críticas antes expuestas, surgen las teorías mixtas o eclécticas, que proponen soluciones integradoras entre las teorías absolutas y relativas. Dentro de esta corriente, encontramos una teoría reflejada en los postulados de Welzel ${ }^{113}$, que reconoce una naturaleza retributiva en la pena, pero que tratándose de ciertos infractores, sostiene que es necesario proceder con criterios preventivos especiales. Otros ejercicios, como aquel desarrollado por Merkel $^{114}$, han tratado de combinar la retribución con la prevención general, mientras que una tercera combinación buscó ensalzar el carácter eminentemente preventivo general de la pena, pero reconociendo y uniendo los postulados prevencionistas especiales. En todos estos casos, como reconoce Bustos, haciendo suyo el argumento de Roxin, los problemas antes expuestos respecto de las teorías retribucionistas y preventivo generales o especiales, no han sido en general solucionados a través de estas construcciones eclécticas. Así, más bien los "efectos de cada teoría no se suprimen en absoluto entre sí, sino que se multiplican". ${ }^{115}$

Especial mención, sin duda, merece la posición de este último autor alemán, que tratando de evitar yuxtaposiciones artificiales, postula que se debe atribuir distintas funciones a la pena, dependiendo de las distintas fases o momentos en que opera: fases de conminación, imposición y ejecución. Conforme lo anterior, en su construcción, la pena tendría en su primera fase (legislativa) una función preventivo general; en la segunda (jurisdiccional), para efectos de su imposición, tendría el carácter de retributiva, y por ende proporcional, junto con un fin de prevención general; mientras que en la última etapa, de ejecución de la pena, esta sería eminentemente preventivo-especial. En relación a esta última posición, Bustos señala que si bien las posibilidades de caer en arbitrariedad se ven reducidas o impedidas por el condicionamiento que le imponen los otros momentos, el énfasis de todas formas está centrado en la prevención, ya que el contenido retributivo sólo se refleja en la forma de administrar la justicia y, en particular, en la prevención especial, apareciendo con ello las criticas en toda su extensión, tanto respecto de la prevención general como de la especial. ${ }^{116}$

En definitiva, para Bustos tanto las posiciones absolutas como las relativas, en su dimensión general y especial, están basadas en "pura ideología y en planteamientos axiomáticos que cubren una realidad diferente", ${ }^{117}$ y es por eso, que la dogmática ha podido convivir sin grandes dificultades con estas últimas. Utilizando los criterios argumentativos ya descritos en párrafos anteriores, él señala que no es necesario recurrir a ningún argumento radical para llegar a la conclusión que cualquier intervención punitiva del Estado, como sea que se denomine esa

\footnotetext{
113 Vid. WELZEL, Op. cit.

114 Vid. MERKEL, Derecho Penal, La España Moderna, Madrid, s/f, citado por BUSTOS, Op. cit., pp.131.

115 ROXIN, Op. cit., pp. 12 y ss, citado por BUSTOS, Op. cit., pp. 132.

116 BUSTOS, Op. cit., pp. 134.

117 Op. cit., Tomo II, pp. 16.
} 
Morales - Las huellas de la criminología crítica...

intervención, tendrá siempre un efecto estigmatizador sobre el sujeto, como ya fuera argumentado por la teoría del etiquetamiento. En ese estado de las cosas, dicha intervención será para él más bien una forma de "seleccionar y aislar a ciertos sujetos y con ello a un grupo social, que servirán siempre de chivos expiatorios", ${ }^{118}$ y la pena - siendo ésto lo único que se ha podido comprobar a través de estudios, como los de prisionización- tanto en su concepción abstracta como concreta, será "siempre un proceso de dominación y de destrucción de sujetos del cuerpo social". ${ }^{119}$ Por ello, para él, a través de la teoría de la pena, se debe poner de manifiesto tales efectos y lograr su reducción al mínimo, a través del otorgamiento del máximo de garantías en relación a la pena y el desmontamiento de "todo el sistema de la penas privativas de la libertad" ${ }^{120}$, junto con el ofrecimiento de nuevas opciones y alternativas al sujeto, en especial, a través de la utilización de formas "no penales de resolución de conflicto y de ofrecimiento de alternativas, con lo cual se puede también ir reduciendo el campo del control penal". ${ }^{121}$

Considerando los problemas que presentan las teorías tradicionales analizadas y a partir de los postulados de la criminología crítica, Bustos emprendió la tarea de construir una teoría de la pena capaz de ser reflejo de las desigualdades e injusticias del derecho penal. Resumiendo sus postulados, Bustos precisa que hay que distinguir entre dos niveles de discusión: aquel referido a qué es la pena y el otro referido a su imposición. Uno aparecería ligado a la "razón en sí y otro a la razón práctica". ${ }^{122}$

En cuanto al primer aspecto, Bustos concibe la pena dentro del sistema penal como una autoconstatación del Estado. ${ }^{123}$ De esta forma la pena es entendida como una constatación de carácter ideológico, por el cual el Estado "demuestra su existencia frente a todos los ciudadanos, señala[ndo] que el sistema por él elegido sigue vigente". ${ }^{124}$ Así mediante la pena, el Estado al autoconstatarse ideológicamente, "ejerce la función de protección de su sistema, luego de los bienes jurídicos que ha fijado, en definitiva, de las relaciones concretas que ha determinado". ${ }^{125}$

En ese orden de ideas, Bustos postula que a lo sumo se pueden atribuir funciones, mas no fines a la pena, bastándose ella a sí misma dado su carácter simbólico. Esto, pues la pena sólo puede autoconstatar y proteger mediante su coacción, pero no puede pretender motivar, toda vez que al no ser comprobable

\footnotetext{
118 Ibid.

119 Ibid.

120 Ibid.

121 Ibid.

122 Op. cit., Tomo I, pp. 136.

${ }_{123}$ Op. cit., Tomo II, pp. 19.

124 Op. cit., Tomo I, pp.136.

${ }^{125}$ Ibid.
} 
dicho carácter, ello queda más allá de sus posibilidades de legitimación en un Estado Democrático de Derecho. A partir de lo anterior, Bustos señala que la misión que le corresponde al jurista es de evaluar críticamente dicha autoconstatación ideológica y consecuentemente de los fines que son objeto de protección, función de revisión que también debiera desarrollar el Estado, de manera de "llevar a cabo una política de descriminalización como también de criminalización desde otra perspectiva". ${ }^{126}$

En cuanto al segundo aspecto, esto es, el de la imposición, Bustos sostiene que la pena sólo puede tener un carácter individual, es decir, dirigida al hombre concreto, y que debe tener como base fundamental la consideración de la dignidad humana. De ahí que para efectos de la pena, el hombre debe ser considerado un fin en sí mismo y no puede, por lo tanto, ser un instrumento del Estado para la consecución de sus fines. ${ }^{127}$ De esta forma, el reconocer la dignidad del hombre, supone primero el evitar la imposición de la pena, y que por lo tanto el Estado ofrezca todas las posibilidades para que no se cometan delitos y que al mismo tiempo, las penas estén limitadas, siguiendo a Beccaria, "al vínculo necesario para tener unidos los intereses particulares" ${ }^{128}$, es decir, no más allá de los "estrictos límites de necesidad de auto constatación indispensables del Estado". ${ }^{29}$ Lo anterior supone reconocer al Estado en su conjunto como corresponsable en el delito, ya que, como es el Estado el que los define, deberá "preocuparse también de establecer las condiciones más favorables para que el individuo particular no delinca". ${ }^{130}$

Así, entendiendo que en la sociedad no hay buenos ni malos desmitificando la idea de la resocialización- y considerando que en particular el delito es más bien, -conforme la teoría del etiquetamiento- "un problema de definición", por la cual habrían hombres que "por diferentes razones, fundamentalmente sociales, entran en conflicto con el orden fijado por el Estado", ${ }^{131}$ se deduce que estamos frente a un problema esencialmente político, donde el Estado está, llamado a allanar los conflictos. ${ }^{132}$ Es por esto que la actividad del Estado frente al delito debe ser concebida desde la prevención, suponiendo "en primer lugar, toda una actividad destinada a prever y evitar esos conflictos, en segundo lugar, a remediar los problemas particulares que los propios individuos voluntariamente presenten para resolver tales conflictos y, por último, ofrecer diferentes alternativas a esos sujetos para resolver esos conflictos.". ${ }^{133}$

\footnotetext{
${ }^{126}$ Ibid., pp. 139.

${ }^{127}$ Ibid.

128 BECCARIA, De los delitos y las penas, citado por BUSTOS, Ibid.

129 BUSTOS, Op. cit.

${ }^{130}$ Ibid.

${ }^{131}$ Ibid.

132 Ibid.

133 Ibid., pp. 139 y 140.
} 
Morales - Las huellas de la criminología crítica...

En resumen, considerando que para Bustos la pena tiene un fin simbólico de autoconstatación del Estado, y de protección de los bienes jurídicos o relaciones sociales determinadas por el Estado, los bienes jurídicos se constituyen en la base de fundamentación y legitimación de la pena, y por ello, son requisito sine qua non de la pena. ${ }^{134}$ De ahí que para Bustos, una definición político criminal de la pena pasa necesariamente por una definición de los bienes jurídicos y que, por su parte, lo único que hace el ordenamiento jurídico es recoger una determinada relación social en formas concretas y simbólicas (vida, salud individual, honor y libertad), relación que, en la medida que importa una determinada posición de sujetos entre sí y de intermediación con otros entes u objetos, será siempre una relación dialéctica. ${ }^{135}$ Así entendido el asunto, el bien jurídico opera, para Bustos, como fundamento y límite material del injusto penal y como fundamento y legitimación misma de la pena. ${ }^{136}$

\section{Reformulación de la teoría penal desde una perspectiva político criminal: posición de Bustos}

Tomando como punto de partida las revisiones anteriores, entendiendo, por lo tanto, que el derecho penal no puede estar ajeno a la realidad social, sino que debe actuar en dicha realidad, y que debe tener como base un planteamiento políticocriminal sustentado en una revisión crítica, Bustos plantea que en el derecho penal se debe distinguir entre tres teorías diferentes: la del delito, la del sujeto responsable y la de la determinación de la pena. ${ }^{137}$ En efecto, para él no es posible analizar la culpabilidad dentro la teoría del delito como ocurre en los análisis tradicionales, toda que vez que tienen a su entender un fundamento distinto del injusto. De ahí a que, para él, la teoría del delito esta compuesta por el hecho típico y antijurídico, cuyo fundamento radica en la protección de bienes jurídicos, entendidos estos como relaciones sociales concretas, y garantizada, por el principio de lesividad, donde sólo se considerarán las afecciones al bien jurídico (lesiones o puesta en peligro concreto). ${ }^{138}$

Luego, es en la teoría del sujeto responsable, donde Bustos ubica la culpabilidad, aunque con una visión distinta de dicho elemento. De esta forma, él se aparta de los conceptos tradicionales en la medida que la entiende, no sólo en función del sujeto, a través del reconocimiento y protección de la autonomía ética de la persona, sino que también ligada a la posibilidad de que el Estado le pueda exigir una respuesta determinada. En consecuencia, desde el punto de vista del Estado y su intervención punitiva, implica examinar si el Estado está en capacidad de exigir una respuesta determinada a una persona y, por lo tanto, considerar si éste le ha dado las condiciones para exigir esa respuesta. De ahí que los conceptos

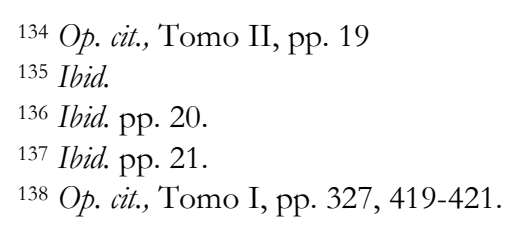


imputabilidad o inimputabilidad no sean adecuados a dicha relación y debamos referirnos a la exigibilidad (de la conciencia del injusto y de la conducta). ${ }^{139}$ Como plantea Bustos, estamos una vez más ante un "concepto político, no ontológico, de interrelación y organización social. No se trata, como en teorías tradicionales, de la culpabilidad de una estructura del ser, de la capacidad de obrar de otra manera, del libre albedrío, sino de la relación existente entre la persona y el Estado". ${ }^{140}$

Finalmente, en relación a la determinación de la pena, ésta viene deslindada no sólo por la dignidad de la persona, tomando como base su autonomía, sino que también por el principio de la indemnidad de la persona. Es por esto que opera siempre limitada por el principio garantista de la necesidad de la pena y, por lo tanto, lleve a considerar "todas las consecuencias que pueda tener la pena sobre la persona y evitar que ésta no esté en relación con el daño causado". ${ }^{141}$

\section{A modo de epílogo}

El presente artículo tuvo como objetivo principal dar a conocer la revisión que hiciere Bustos de las bases del derecho penal, a la luz de la criminología crítica. En esa tarea, considerando que dicho autor no efectúo un análisis pormenorizado de los postulados de ese pensamiento criminológico, preferimos hacer un repaso por sus principales y más connotados representantes. De lo expuesto, claramente se desprende que no hay una visión unívoca respecto de sus postulados y tampoco se encuentra, por cierto, una sola forma de respuesta frente a los problemas detectados en relación al proceso de criminalización desigual y al hecho que el derecho penal surja como instrumento de control social de las clases dominantes sobre aquellas más desposeídas.

Como se observa, uno de los principales aportes de la criminología crítica recogiendo los aportes de la sociología-, radica en haber dejado de lado los análisis positivistas que ponían el acento en el delincuente, pasando a preocuparse por el entorno en que se desarrolla la criminalidad, centrándose en el análisis de la sociedad que los castiga, etiqueta y criminaliza, a través de sus instancias de control y de reacción social; y donde el derecho penal, surge como la más importante de las herramientas de control. Desde esa perspectiva, no es posible desconocer una de las más importantes objeciones planteadas a la criminología crítica y, en particular, a los movimientos "contrarreformistas" -como los denominara Larrauri- de haber hecho suyos los conceptos y categorías tradicionales acerca del delito y la cuestión del crimen, en circunstancias que el examen de dichas categorías debiera ser el punto de inicio de cualquier análisis criminológico. Extendiendo aún más el argumento, autores como Feijoo, en una crítica reciente a esta corriente de pensamiento, han planteado como una de las falencias de la

\footnotetext{
${ }^{139}$ Ibid., pp. 420- 421.

140 Ibid., pp. 420.

${ }^{141}$ Ibid., pp. 421.
} 
Morales - Las huellas de la criminología crítica...

criminología crítica el "no ha[ber] desarrollado una teoría del derecho penal o una teoría que explique el funcionamiento del derecho penal, sino que ha[ber] planteado una estrategia anti (derecho penal, pena, dogmática jurídico-penal, criminología ortodoxa, etc.)". ${ }^{142}$ Es precisamente en éste último punto, que la obra de Bustos aparece como una respuesta a dichas críticas, en la medida que a través de su obra, no sólo efectuó un examen crítico de las bases del derecho penal moderno -cuestionando los principios de la igualdad, libertad y justicia- y abogó por un derecho penal que reconociera que el sistema es de por si desigual e injusto y que la libertad, al igual que los otros dos principios, se ha fundamentado tradicionalmente en pura ideología; sino que a partir de dicho análisis, él se permitió repensar las teorías de las normas, del bien jurídico y de la pena, para luego realizar una construcción del derecho penal, que precisamente recogiera dichos postulados críticos.

Por otro lado, no es posible desatender aquellas objeciones a esta corriente criminológica, que apunta a la excesiva ideologización de los postulados, donde sus críticas, por ejemplo a la pena, no sólo se refieren a su función dentro del sistema penal, sino que más bien a la función que le corresponde en "unas sociedades que no les gusta[n] y que quieren cambiar"; ${ }^{143}$ y donde se entrega al derecho penal funciones que no le son propias, entendiendo que, a través de los instrumentos penales, no es posible corregir las deficiencias estructurales de la sociedad, volviendo al examen sobre las verdaderas causas de la criminalidad. Esta crítica es sin duda acertada, pues incluso los adherentes a esta corriente reconocen y entienden que el problema radica no en el derecho penal mismo, sino en estructuras sociales del capitalismo y las formas en que se manifiesta su dominación a través de herramientas de control, donde una de ella es, por cierto, el derecho penal. De ahí que no sea correcto, como han planteado autores como Silva Sánchez ${ }^{144}$ o García-Pablos ${ }^{145}$ atribuir una función promocional de transformación del orden social al derecho penal, entendiendo que a éste último no le compete trasformar los principios de organización de la sociedad.

Sin embargo, no es menos cierto, como lo han planteado diversos autores, que el Derecho no puede estar alejado de la realidad social dentro de la cual se ejerce, toda vez que el actuar de los sujetos se circunscribe precisamente en determinados entornos sociales. En efecto, el pretender una construcción dogmática totalmente hermética y aislada del entorno social sobre la base de construcciones como la igualdad, la justicia y la libertad, importa, igualmente, caer en ideologías y construcciones jurídicas que en nada se acercan a la realidad. Sino que -como ya se ha señalado majaderamente en distintos foros- basta con apreciar

\footnotetext{
142 FEIJOO, Retribución y Prevención General. Un estudio sobre la Teoría de la pena y las funciones del Derecho Penal, Editorial B de F, Buenos Aires, 2007, pp. 341.

143 Op. cit., pp. 344.

144 Vid. SILVA SÁNCHEZ, La expansión del Derecho Penal: aspectos de la política criminal en las sociedades postindustriales, Madrid, 2001.

145 Vid. GARCÍA-PABLOS, Criminología. Una introducción a sus fundamentos teóricos, Valencia, 2005.
} 
las realidades penitenciarias, para darse cuenta que la criminalización selectiva y desigual no puede ser sólo fruto de la coincidencia. Por otro lado, las objeciones a la excesiva ideologización de la corriente crítica, se olvidan -como bien lo planteó Bustos- que las concepciones tradicionales sobre los principios del derecho penal, las teorías del delito y de la pena, tienen también un fundamento ideológico, basado en construcciones individualistas como ocurre con la noción moderna del principio de culpabilidad.

De ahí que estos tipos de pensamientos críticos, no sólo tengan por objeto revivir antiguas teorías y adaptarlas de manera de construir alternativas al Derecho vigente, sino que sirvan para repensar el derecho penal y evaluar alternativas que recojan -al menos en parte- dichas deficiencias estructurales, buscando respuestas más satisfactorias y acordes a la realidad, que aquellas entregadas por el derecho penal tradicional, como ocurre con la reparación o la mediación. En efecto, estos últimos institutos, manifestaciones de lo que Bustos denominó "Derecho Penal de alternativas", descansan en procesos comunicativos y dialogales, mucho más enraizados en el conflicto real y los que, sin duda, están siendo recogidos por legislaciones como la chilena ${ }^{146}$ dejando de ser sólo objetos de atención académica o meros postulados ideológicos, surgiendo como alternativas necesarias frente a la crisis de la pena privativa de la libertad.

\footnotetext{
146 En efecto, la reparación está regulada en el Código de Procesal Penal Chileno, artículo 241, como una salida alternativa, mientras que la Ley N²0.084 de responsabilidad penal adolescente, en su artículo 10 la reconoce como una de las penas a aplicar. Sobre su construcción normativa y justificación dogmática, Vid. MORALES Las salidas alternativas y las sanciones no privativas de libertad de reparación del daño y servicios en beneficio de la comunidad en el subsistema de responsabilidad penal de adolescentes infractores de la ley penal, en Revista de Estudios de la Justicia, N 7, Santiago, 2006.
} 
Morales - Las huellas de la criminología crítica...

\section{BIBLIOGRAFÍA}

* ANITUA, Gabriel: Historias de los pensamientos criminológicos, Editores del Puerto, Buenos Aires, 2005.

* BARATTA, Alessandro: Criminología crítica y crítica del Derecho Penal, Siglo veintiuno Editores, Buenos Aires, 2002.

"Principios del Derecho Penal Mínimo" en Criminología y Sistema Penal (Compilación in memoriam), Editorial B de F, Buenos Aires, 2004.

* Bergalli, Roberto; Bustos, Juan; Millares, María Teresa, El pensamiento criminológico, Tomo I, Editorial Temis, Bogotá, 1983.

* Bustos, Juan: Obras completas, Derecho Penal, Parte General, Tomo I, Ediciones Jurídicas, Santiago, 2007. 2007.

Obras completas, Control social y otros cambios, Tomo II, Ediciones Jurídicas, Santiago,

* COHEN, Stanley: Prólogo en Larrauri, La Herencia de la criminología crítica, Siglo veintiuno de España Editores, Madrid, 1991.

* DOWNES, David; Rock Paul: Understanding Deviance, Oxford University Press, Oxford, 2003.

* FEIJOO, Bernardo: Retribución y Prevención General. Un estudio sobre la Teoría de la pena y las funciones del Derecho Penal, Editorial B de F, Buenos Aires, 2007.

* GARCÍA-PABLOS, Antonio: Criminología. Una introducción a sus fundamentos tóricos, Tirant Lo Blanch, Valencia, 2005.

* GaRLAND, David: La Cultura del Control, Gédisa, Barcelona, 2005.

* HIL, Richard: "Facing Change: New directions for critical criminology en the early new millennium?", en Western Criminology Review. Artículo en Internet http://wcr.sonoma.edu/v3n2/hil.html.

* KAUfMAN, Armin: Teoría de las normas, Ediciones Depalma, Buenos Aires, 1977.

* LACEY, Nicola: State Punishment. Politics Principles and community values, Routledge, Londres, 1988.

* LARRAURI, Helena: La Herencia de la criminología crítica, $2^{\circ}$ Ed., Siglo veintiuno de España Editores, Madrid, 1991.

* LEA, John; Young, Jock: ¿Qué hacer con la ley y el orden?, Editores del Puerto, Buenos Aires, 2001.

* MARTINSON, Robert: "What Works? Questions and Answers About Prison Reform", The Public Interest, vol. 35, 1974.

* MORALES, Ana María: "Las salidas alternativas y las sanciones no privativas de libertad de reparación del daño y servicios en beneficio de la comunidad en el subsistema de responsabilidad penal de adolescentes infractores de la ley penal", Revista de Estudios de la Justicia 7, Santiago, 2006.

* MUNCIE, John: "Reassessing competing paradigms in contemporary criminological theory", en WALTON/YOUNG (ed.) The new criminology revisited, Macmillan, Londres, 1998.

* O’MALley, Pat: "Volatile and contradictory punishment" en Theoretical Criminology 3, Sage Publications, Londres, 1999.

* REIMAN, Jeffrey: The rich Get Richer and The Poor Get Prison, Macmillan, Nueva York, 1990.

* ROXIN, Claus: Problemas básicos de Derecho Penal, Reus, Madrid, 1976.

* SILVA SÁNCHEZ, Jesús M.: La expansión del Derecho Penal: aspectos de la política criminal en las sociedades postindustriales, Civitas, Madrid, 2001.

- TAYLOR, Ian; Paul, Walton; Young, Jock.: La nueva criminología, $3^{\circ}$ Ed, Amorrortu Editores, Buenos Aires, 2007. 
REJ - Revista de Estudios de la Justicia - No 12 - Año 2010

(Ed.) Critical Criminology, Routledge, Londres, 1975.

- VON HIRSCH, Andrew: Censurar y castigar, Trotta, Madrid, 1998.

* VON LISZT, Franz: Tratado de Derecho Penal, Tomo II, Editores Reus, Madrid, 1927.

* WACQUANT, Loic: Las Cárceles de la Miseria, Manantial, Buenos Aires, 2004. 